\title{
SIMULTANEOUS SACCHARIFICATION AND FERMENTATION OF BANANA (MUSA ACUMINATA) PEEL FOR BIOETHANOL PRODUCTION
}

\author{
An T.T. Tran', Quan D. Nguyen ${ }^{2}$, Phung T.K. Le ${ }^{3}$ \\ *l,2 Laboratory of Biofuel and Biomass Research \\ ${ }^{2,3}$ Department of Chemical Process Engineering and Equipment, Ho Chi Minh University of Technology, Vietnam
}

*Corresponding Author: -

Email: trantuongan@hcmut.edu.vn, trantuongan81@gmail.com

\begin{abstract}
: -
Banana (Musa acuminata) peel is discarded after the fruit processing process. Banana peel biomass can be used as raw material to produce bioethanol. In this research, banana peel was fermented by simultaneous saccharification and fermentation using Saccharomyces cerevisiae. Production of bioethanol was determined and the effects of various operation conditions which included different parameters in fermentation process: fermentation time, temperature, medium $\mathrm{pH}$, concentration of yeast, enzyme loading, and shaking period. peel was cut, pretreated with $\mathrm{H}_{2} \mathrm{SO}_{4} 2 \%$ and simultaneous hydrolyzed and fermented. Ethanol production was greatest (over 10,5\%) when the initial pH of fermentation medium was adjusted to 4.5, 5\% yeast supplement $\left(8 \times 10^{7} \mathrm{cfu} / \mathrm{ml}\right), 7 \%$ cellulase $(100 \mathrm{IU}, \mathrm{v} / \mathrm{v})$ loading, 24 hours and $37^{\circ} \mathrm{C}$ incubating,. The results illustrated that the simultaneous saccharification and fermentation (SSF) of banana peel with S.cerevisiae has potential for industrial application.
\end{abstract}

Keywords: - Banana peel, Musa acuminata, bioethanol, cellulase, fermentation

\section{(c) $(\$)$ (i)}




\section{INTRODUCTION}

Urban pollution, global warming and reserves depletion of fossil fuels have been the driving forces for current research on alternative energy sources, especially which derived from fruit waste. Bioethanol produced from different renewable fruit waste contributes an alternative fuel for engines.

Using bioethanol as a fuel decreases fossil fuel consumption and provides energy supply security. It can be used puried or mixed with gasoline. Besides, bioethanol is considered biodegradable and sulphur free. Carbon content of bioethanol has a vegetable origin and as a consequence, when it is released during the combustion process, it does not contribute to the increase of $\mathrm{CO} 2$ content in the atmosphere, reducing environmental polution [1].

The production of bioethanol by fermentation faces competition with bioethanol industry from petroleum. But with the increasing value of these petrochemical feedstocks, bioethanol fermentation is more interest and more attention [2]. In this regard, use of fruit waste will be more economical, because they are cheap and easily available.

Many countries over the world use fruit waste as option rather than use food supply for energy production, like Zimbabwe and Australia. In Zimbabwe, many projects have been performed on energy industry from crop residues. The total energy consumption was over 44\% in Zimbabwe which came from agro-waste [3].

Banana (Musa acuminata) is one of the tropical fruits that belong to Musacea. In Vietnam, the total area of banana is over 100,000ha. The peel is waste materials resulting from the banana confectionery processing and disable fruits, they are normally discarded. These discarded peels may cause the environmental pollution, particularly water pollution. Thus, in addition to making fertilizer, the peels can be used in the production of bioethanol, which would then increase the potential producing and value for the banana.

Most of the researches which produce bioethanol were conducted with seperated hydrolysis and fermentation method. Currently, due to the SSF process has many favorable advantages (reduced equipment costs, enzyme costs, ethanol formed during the process to facilitate the continuous production...), the bioethanol production plants changes to research to bioethanol produce by SSF method.

The objectives of this work were to investigate the effect of operating condition to the ethanol simultaneous saccharification and fermentation from banana peel on a laboratory scale including fermentation time, temperature, addition of yeast, addition of enzyme, $\mathrm{pH}$ of medium and shaking.

\section{MATERIALS AND METHODS}

\section{A. Raw materials}

Banana (Musa acuminata) peel were harvested at confectionery processing factories in Ho Chi Minh city, Vietnam. The grounded peel was then dried in a dryer oven at $60^{\circ} \mathrm{C}$ for $24 \mathrm{~h}$ to reach the moisture content of $10 \pm 1 \%$. Subsequently, the dehydrated peels were grounded to powder by food processor (Phillip, Holland) and packed polyethylene bags, sealed and stored at $5^{\circ} \mathrm{C}$. These treated peels were used for bioethanol fermentation.

Cellulase was provided from Brenntag Company, Viscozym Cassava C.

The yeast strain Saccharomyces cerevisiae ATCC was obtained from American Collection for Type Culture (ATCC, America) and activated in $10 \mathrm{ml}$ of Saubouraud Dextrose Broth (SDB) which consisted of glucose $30 \mathrm{~g} / \mathrm{l}$, peptone $10 \mathrm{~g} / \mathrm{l}$. The yeast inoculums was placed in a $250 \mathrm{ml}$ erlene containing $100 \mathrm{ml}$ autoclaved SDB for 48 hour at room temperature.

\section{B. Methods}

\section{1) Chemical Analysis:}

Research some chemical composition of banana peel which includes: 1) moisture content (was determined by infrared dryer Mettler Toledo, at $108^{\circ} \mathrm{C}$ ), 2) total soluble solids (was determined by Atago digital refractometer, Japan), 3) $\mathrm{pH}$ (was determined by Hanna instrument), 4) reducing sugar content (using DNS reagent, as Miller method) [5], 6) cellulose content [4] and 7) lignin content (as Klason method), 8) Alcohol percentage in all fermentations were determined by using HPLC.

\section{2) Pretreatment of Dried Banana Peel:}

In this study, some pretreatments method were applied to treating the dried banana peel as follow: $-\mathrm{H}_{2} \mathrm{SO}_{4}: 2,3,4,5 \%$ during 5 days

- $\mathrm{NaOH}: 0.25,0.5,0.75,1.0 \%$ during 5 days

- Pressing: $1 \mathrm{~atm}, 121^{\circ} \mathrm{C}$ during $10,20,30$ minutes

\section{3) Bioethanol Simultaneous Saccharification and Fermentation:}

SSF were conducted using a Viscozyme cassava C (Brenntag) and Saccharomyces cerevisiae. SSF also conducted 250 $\mathrm{mL}$ flask, enzyme was added at the beginning and the biomass was hydrolyzed at $50^{\circ} \mathrm{C}, \mathrm{pH} 5.0$, static culture.

$10 \mathrm{~g}$ dried banana peel was weighed into $250 \mathrm{ml}$ erlene and $100 \mathrm{ml}$ distilled water was added. This was autoclaved at $121^{\circ} \mathrm{C}$, $1 \mathrm{~atm}, 15$ minutes. The fermentation was then monitored from 15 hour to 96 hour. Different concentrations of the yeast were used and the $\mathrm{pH}$ of sample was also adjusted with $\mathrm{NaOH} 0.5 \mathrm{~N}, \mathrm{pH} \sim 5.0$. The inoculated media were incubated in anaerobic condition. At the end of the fermentation, the fermented sample was centrifuged, 5000 round per min (rpm), 5 minute. Measuring the reducing sugar and ethanol content.

Based on bioethanol procedure, the influences of six factors were investigated. The experiment plant is represented in Table 1. The optimum result of previous experiment would be applied in the next experiment. All experiments were carried out in triplicate. 


\section{TABLE I}

EXPERIMENT PLANT OF FERMENTATION CONDITIONS OF DRIED BANANA PEEL

\begin{tabular}{ccccccc}
\hline $\begin{array}{c}\text { Factor/ } \\
\text { Method }\end{array}$ & $\begin{array}{c}\text { Fermentation } \\
\text { time }(\mathrm{h})\end{array}$ & $\begin{array}{c}\text { Fermentation } \\
\text { temperature }\left({ }^{\circ} \mathrm{C}\right)\end{array}$ & $\begin{array}{c}\mathbf{p H} \text { of } \\
\text { medium }\end{array}$ & $\begin{array}{c}\text { Yeast adding } \\
(\%, \mathbf{v} / \mathbf{v})\end{array}$ & $\begin{array}{c}\text { Enzyme adding } \\
(\%, \mathbf{v} / \mathbf{v})\end{array}$ & $\begin{array}{c}\text { Shaking } \\
(\mathbf{r p m})\end{array}$ \\
\hline 1 & $0-69$ & $\mathrm{t}^{\circ} \mathrm{room}$ & $4.7-5.0$ & 5 & non \\
\hline $2-4$ & $35,37,40, \mathrm{t}^{\circ} \mathrm{room}$ & $4.7-5.0$ & 5 & non \\
\hline $5-9$ & & $\begin{array}{c}4.0,4.5,5.0 \\
5.5,6.0\end{array}$ & 5 & non \\
\hline $10-13$ & & $\begin{array}{c}2.5,5.0,7.5, \\
10.0\end{array}$ & non \\
\hline $14-17$ & & & $3,4,5,6$, & non \\
\hline $18-20$ & & & & & 50,100, \\
\hline
\end{tabular}

\section{RESULTS AND DISCUSSES}

\section{A. Chemical Composition of Banana Peel}

The chemical composition of banana peel is presented in Table 2. The data indicated that the banana peel is a rich source of sugars, total acidity and total soluble solids content. The dried banana peel contained high amount of reducing sugars (up to $89.43 \mathrm{mg} / \mathrm{g}$ ) and the results are similar to those of previous reports ([6],[7]). The high cellulose content of banana peel could serve as the important source for bioethanol fermentation use microbial culture.

\section{TABLE II}

\section{CHEMICAL COMPOSITION OF BANANA PEEL}

\begin{tabular}{lc}
\hline \multicolumn{1}{c}{ Composition } & Content \\
\hline Moisture (\%) & $82 \pm 2.16$ \\
Ash (\%) & $1.37 \pm 0.1$ \\
Cellulose (\%) & $9.5 \pm 0.01$ \\
Lignin (\%) & $3.12 \pm 0.5$ \\
\hline
\end{tabular}

\begin{tabular}{lr}
\hline \multicolumn{1}{c}{ Composition } & \multicolumn{1}{c}{ Content } \\
\hline Pectin $(\%)$ & $1.33 \pm 1.1$ \\
Total acidity $(\%)$ & $0.14 \pm 0.001$ \\
Reducing sugar $(\mathrm{mg} / \mathrm{g})$ & $1.08 \pm 0.017$ \\
Peel content $(\mathrm{g} / 100 \mathrm{~g})$ & $15.23=2.13$ \\
\hline
\end{tabular}

\section{B. Pretreatment of Banana Peel}

The yields of reducing sugar from the banana peel by different pretreatment methods are shown in Figure 1. The reducing sugar and cellulose content when pretreated with $\mathrm{H}_{2} \mathrm{SO}_{4}$ is higher than with other pretreatments. The glucose content increased when the $\mathrm{H}_{2} \mathrm{SO}_{4}$ concentration increased but decreased after reaching the highest level . This implies that hydrolysis process depend on acid which shows that by increasing concentrations of $\mathrm{H}_{2} \mathrm{SO}_{4}$, it doesn't enhance the hydrolysis performance. However, when the treating process was increased from 4 to 5 days, the glucose production had decreased. Perhaps, by increasing the duration to 5 days, it could play as an inhibitor of improving higher reducing sugar yield.

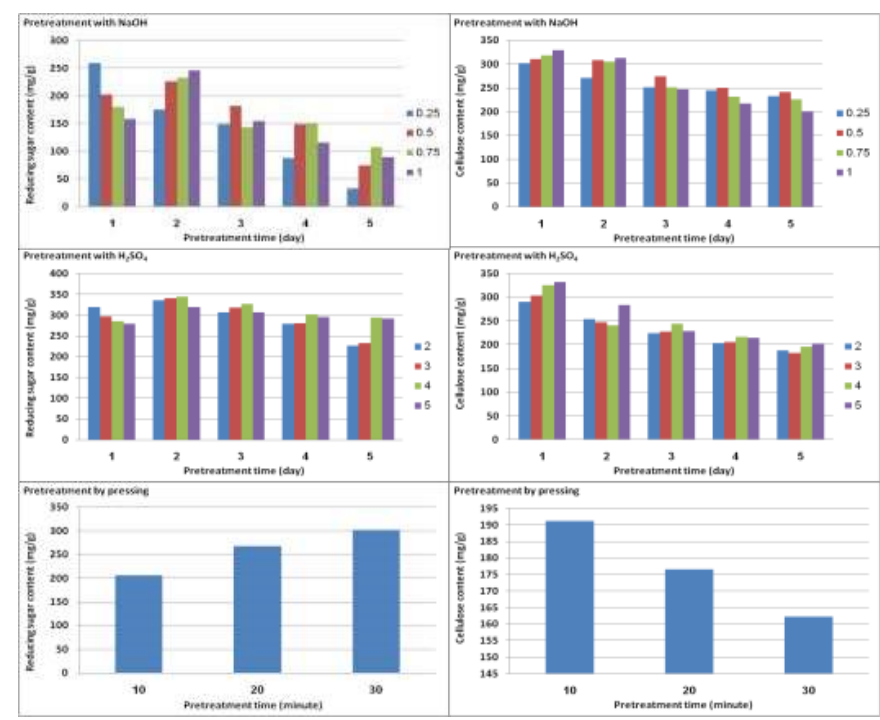

Fig. 1 Effects of pretreatment methods of banana peel to ethanol fermentation

The results showed that the sugar yield was affected significantly $(p<0.05)$ by pretreatment methods. The sugar released $301.5 \mathrm{mg} / \mathrm{g}$. As Sirkar et al [8], acid pretreatment method was optimal for better yield of fermentable sugars from fruit 
peels. Acid, alkaline pretreatment of biomass has been extensively studied and in an experiment using fruit wastes, Patle and Lal [9] has researched reducing sugar yield of $49.84 \mathrm{~g} / \mathrm{L}$ and bioethanol production of $23.32 \mathrm{~g} \mathrm{~L}$ in the HCL pretreated to fruit and vegetable residues and the enzymatic hydrolyzate reached $36.123 \mathrm{~g} / \mathrm{L}$ of reducing sugars and $11.54 \mathrm{~g} / \mathrm{L}$ of ethanol. The initial pretreatment, in case of fibrous peel residues, is needed to breakdown its structure to make it more susceptible to an enzymatic attack, where as for pulp residues, it is required to avoid the necessary for reducing the weight of the biomass and to inhibit fermentative microorganisms which degrade compounds.

\section{Bioethanol Simultaneous Saccharification and Fermentation from Banana Peel 1) Influence of Fermentation Time:}

Fermentation time is an important factor affecting the bioethanol fermentation process. If the time is too short, fermentation does not occur completely, ethanol is produced few. If the time is too long, the fermentation environment will be infected other microorganisms, and if there is the presence of oxygen, the alcohol is oxidized to acetic acid, which reduces the strength and cause alcohol damage. Usually the determination of the end of fermentation process bases on the moment which the total soluble solids value do not change for at least 6 consecutive hours. At the end of fermentation process, yeast cell no longer converts sugar into ethanol, because amount of formed ethanol sufficient inhibits to fermenting. Therefore the determination of appropriate fermentation time is very important.
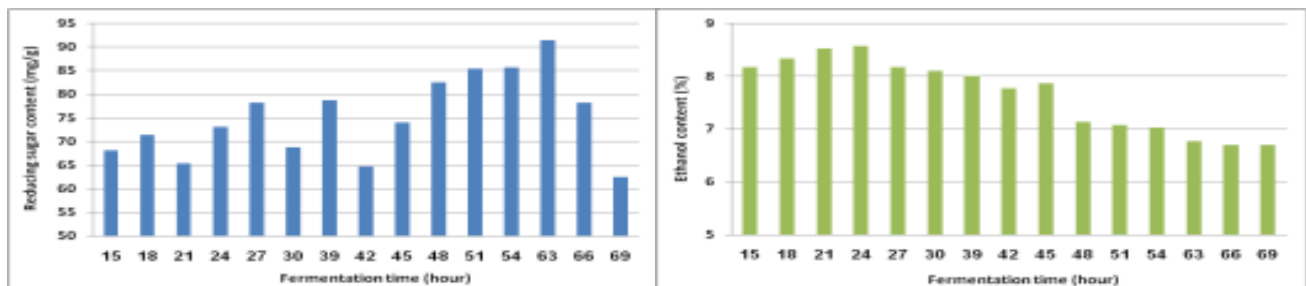

Fig. 2 Influence of fermentation time to the bioethanol fermentation from banana peel

The influence of fermentation time is presented in Fig.3. As soon as yeast cells is inoculated into fermentation medium, because a large amount of oxygen is available, yeast cells consumed sugar and other soluble nutrient molecules for cell division and development, ethanol has not been produced yet. When oxygen became exhausted, yeast cells converted substrate to ethanol molecules in anaerobic condition. Sugar and nutrient molecules were metabolized much at this stage, the rapid fermentation occurred in the period from 15 to $69 \mathrm{hrs}$. Almost all of substrate molecules were converted into ethanol and $\mathrm{CO}_{2}$ and some byproducts such as organic acids, higher alcohol, aldehydes... Thus, medium $\mathrm{pH}$ decreased from 4.50 to 3.97. The alcohol content increased to $8.57 \%$ and the yield of converting reducing sugar increased to $77.62 \%$. The moment of 24 hour is the end of bioethanol fermentation from banana peel. After 24 hour, the reducing sugar content continued to increase, but the ethanol content decrease. The reason is the ethanol concentration $8.53 \%$ inhibited ethanol fermentation and ethanol molecules were converted tho other compounds. This result is similar to the results which were reported in some previous researches. The fermentation time of pawpaw fruit waste is 3 days [11]. Bioethanol was produced from Hylocereus polyrhizus's pericarps for $75 \mathrm{hrs}$ [12]. The maximum ethanol content was obtained after $75 \mathrm{hrs}$ for fermentation process (over $60 \mathrm{~g} / \mathrm{l}$ ) [13].

\section{2) Influence of Temperature:}

The temperature of fermentation can affect the growth of Saccharomyces cerevisae. The yield of ethanol is related to medium temperature. Temperature factor can impact the sensitivity of yeasts in ethanol production, growth rate, rate of fermentation, viability, length of lag phase, enzyme and membrane function... Many yeast strains behave differently in their response towards temperature, therefore their common optimum temperature could not be easily established.

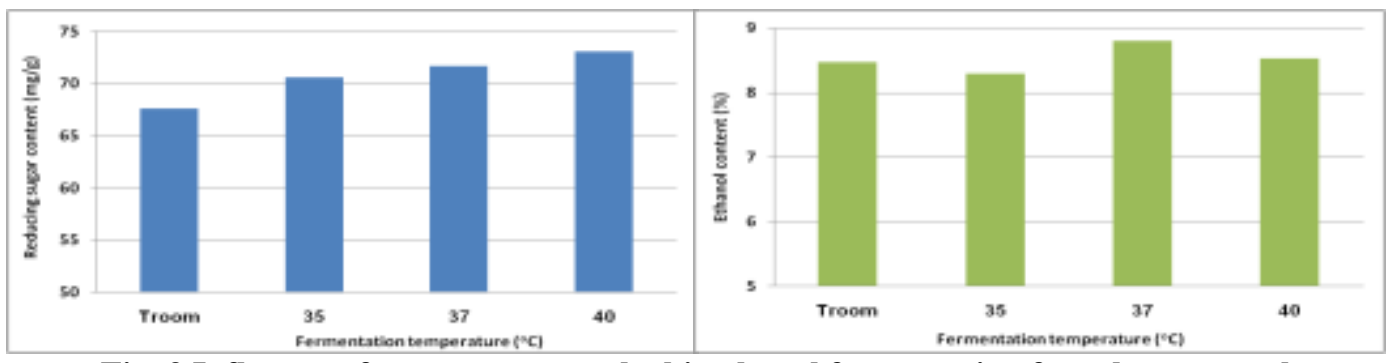

Fig. 3 Influence of temperature to the bioethanol fermentation from banana peel

The results on the variation of ethanol percentage against temperature are represented in Fig.3. The temperature was varied between $25^{\circ} \mathrm{C}$ and $37^{\circ} \mathrm{C}$. The $\mathrm{pH}$ of sample was maintained at 4.5 and fermentation period was kept for 24 hour. The ethanol concentration reached the highest level at $37^{\circ} \mathrm{C}(8.80 \%)$ and decreased not only with the increase in temperature up to $40^{\circ} \mathrm{C}(8.53 \%)$ but also with the decrease in temperature to $35^{\circ} \mathrm{C}(8.30 \%)$. The yield of reducing sugar also reached the highest level as yeast cell lived $37^{\circ} \mathrm{C}$. Yeast does not grow at temperature over $40^{\circ} \mathrm{C}$ and below $30^{\circ} \mathrm{C}$ its growth slows down dramatically. The enzymes activity that catalyzes the biochemical reactions in the yeast cell to function at those separate temperatures. Enzymes have a special optimal temperature degree. When temperature of 
medium goes below the optimal range, catalytic activity of enzyme slows down. On the contrary, when the temperature increases, enzymes will be denatured or unfolded and thus become inactived situation. Even if only one essential enzyme stops working, the organism will fail to grow [14]. Beside, as cellulase activity of commercial enzyme is most appropriate at $40-50^{\circ} \mathrm{C}, 37^{\circ} \mathrm{C}$ is appropriate to activity of yeast cell and enzyme. Similar to this result, the content of ethanol from mango (Mangifera indica L.) peel was optimum at $30-31^{\circ} \mathrm{C}$ [13]. The bioethanol production from banana was maximum at $37^{\circ} \mathrm{C}(8.8 \%)[11]$.

\section{3) Influence of Initial pH:}

The initial $\mathrm{pH}$ factor has significant influence on bioethanol fermentation. To observe the influence of $\mathrm{pH}$ on the quantity of ethanol, the experiments were carried out fermentation period of 24 hour at $37^{\circ} \mathrm{C}$. The $\mathrm{pH}$ value of banana peel samples was varied 4.0-6.0 with an increment of 0.5. This $\mathrm{pH}$ range is selected according to Morris and Sarad [15] and Adams and Flynn [16]. Fig.4 shows the variation of ethanol content (\%) produced with $\mathrm{pH}$. The ethanol content was least of $7.97 \%$ at $\mathrm{pH} 4.5$ and increased to reach the highest value $8.95 \%$ at $\mathrm{pH} 4.5$. At this $\mathrm{pH}$, the $\mathrm{pH}$ different is lowest $(\Delta \mathrm{pH}=0.5)$. However, keep increasing $\mathrm{pH}$ to 6.0 , the ethanol content significant decreased $(8.21 \%)$. The important reason is the optimum initial $\mathrm{pH}$ for the growth of yeast is about 4.5-6.0, and the most appropriated $\mathrm{pH}$ for cellulase activity is about 4.5-5.5. The lower activities of yeast towards bioethanol fermentation are shown at a $\mathrm{pH}$ of 4 because these $\mathrm{pH}$ values are too low to activate the enzymes (of yeast) to run their functions .

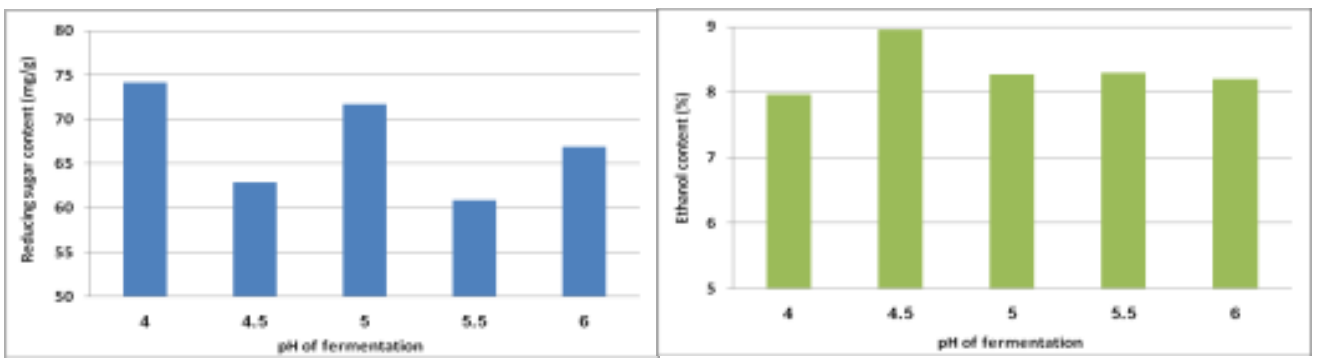

Fig.4. Influence of initial $\mathrm{pH}$ to the bioethanol fermentation from banana peel

\section{4) Influence of Adding of Yeast Culture and Enzyme :}

The yeast culture $\left(10^{8} \mathrm{cfu} / \mathrm{ml}\right)$ and cellulase $(100 \mathrm{IU} / \mathrm{ml})$ was added to fermentation flask with different ratio (v/v). Generally, irrespective of the $\mathrm{pH}$, optimum fermentation period was 24 hour. It was also researched that there was increase in ethanol concentration with increase of yeast concentration (2.5-10\%), enzyme concentration (1-7\%) and reached the yield $(9.37 \%)$ when added $5.0 \%$ yeast culture broth. Yield of converting reducing sugar increased as increased volume of yeast culture. Reducing sugar was converted optimally as carried out the fermentation added 5\% culture (9.37\%) (Fig.5). The ethanol yield continue to increase to $9.73 \%$ when add $7 \%$ enzyme (Fig.6). The reason is when increasing enzyme supplement, the reducing sugar content increased. Beside, with high density of yeast, bioethanol fermentation ability also increased. However, the price of cellulase is high, adding so much enzyme will reduce economic efficiency of bioethanol SSF process.

This observation is consistent with the report of Morris and Sarad [15], which indicated that the amount of yeast influenced ethanol production. As Akin [11], there was increase in bioethanol yield with increase in yeast concentration up to $10 \%$.
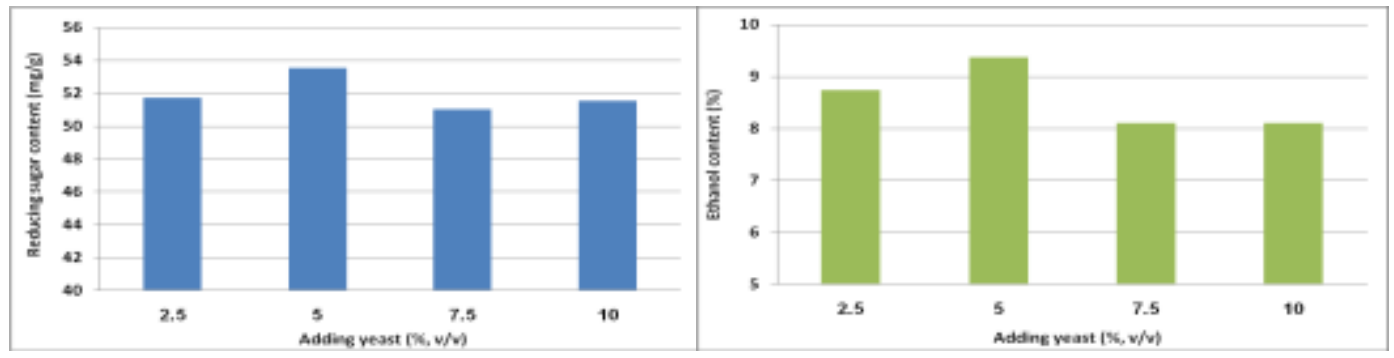

Fig.5 Influence of adding yeast culture to the bioethanol fermentation from banana peel

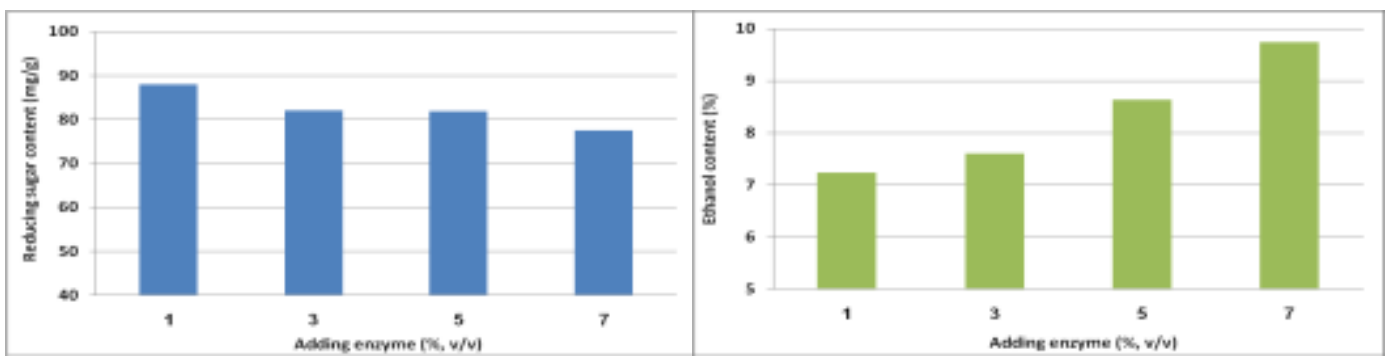

Fig.6 Influence of enzyme addition to the bioethanol fermentation from banana peel 5) Influence of Shaking Rate: 
The concentration of bioethanol at different shaking rate was shown in Figure 7. The fermented banana peel mash that have been shaken for a long time produced higher bioethanol with $10.67 \%$. Based on the data, the reducing sugar content of fermented banana peel were lower than before fermentation. From the $\mathrm{pH}$ results, measurements of the $\mathrm{pH}$ before fermentation (4.5) were higher than after fermentation (4.10). The $\mathrm{pH}$ of the fermented banana peel mash without shaking exhibited the higher value than those that have been shake 50rpm. Shaking make a clear medium, yeast cells approach and take nutrient molecules better, so yeast cells growed and actived better, the fementation rate was also faster. However, the shaking rate was increased faster $(100 \mathrm{rpm})$ would affect and inhibit the activity of yeast cell.
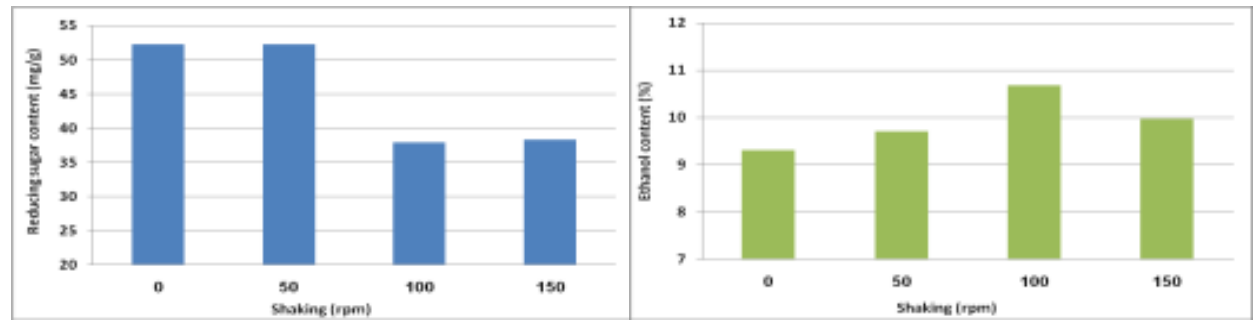

Fig.7 Influence of shaking to the bioethanol fermentation from banana peel

\section{CONCLUSION}

In this study, banana peel was proved as one of the potential raw material for bioethanol production by simultaneous saccharification and fermentation. Studies on peel hydrolysis using commercial enzyme will make the process economically. Optimization of fermentation conditions includes fermentation time, temperature, initial $\mathrm{pH}$, adding yeast culture, adding enzyme, shaking enhanced the fermentation rate and final ethanol concentration. The final ethanol concentration of SSF from banana peel is $10.67 \%$, this concentration is higher than separated hydrolysis and fermentation form banana peel $(8.91 \%$, control experiment) and is much higher than bioethanol production with banana peel which is not pretreatment $(5.11 \%$, control experiment).

\section{REFERENCES}

[1].Hsieh, W., et al. 2002. "Engine Performance and Pollutant Emission of an SI Engine Using Ethanol-Gasoline Blended Fuels", Atmospheric Environment Vol. 36, pp. 403-410.

[2].Sirkar, A., Das, R., Chowdhury, S., \& Sahu, S.J. (2008). An experimental study and mathematical modelling of ethanol production from banana peels by hydrolysis and fermentation. 88: 4-10.

[3].Jingura RM, Matengaifa R. 2008. Optimisation of biogas production by anaerobic digestion for sustainable energy development in Zimbabwe. Renew. Sustain. Energ. Rev. Article in press.

[4].AOAC, 2000. Association of Official Analytical Chemists. 17th Edn., AOAC, Washington, DC., pp: 21-447.

[5].Miller GC (1959). Use of the Dinitrosalicylic Acid Reagent for the Determination of Reducing Sugar. Analytical Chemists. 31: 420 - 428.

[6].Anonymous (2004). By-products and waste utilization (value addition of mango processing waste). Food Digest. 27 : 14-17.

[7].Madhukara K, Krishnanad N, Srilatha HR (1993). Ensilage of mango peel for methane generation. Process Biochem., 28: 119-123.

[8].Sirkar, A., Das, R., Chowdhury, S., \& Sahu, S.J. (2008). An experimental study and mathematical modelling of ethanol production from banana peels by hydrolysis and fermentation. 88: 4-10.

[9].Patle, S., \& Lal, B. (2007). Ethanol production from hydrolysed agricultural wastes using mixed culture of and . 29: 18391843.

[10]. Singh, A., Das, K., \& Sharma, D.K. (1984). Production of Xylose, furfural, fermentable sugars and ethanol from agricultural residues. 34A: 5161.

[11]. B.C. Akin-Osanaiye, H.C. Nzelibe and A.S. Agbaji. 2008. Ethanol production from Carica papaya (paw paw) fruit wate, Asian journal of Biochemistry, 3(3), 188-193.

[12]. S.L.Hii, T.Y.Ding and L.G.A. Ong. 2010. Comparative Evaluation of Pretreatment strategies on enzymatic saccharification of Hylocereus polyrhizus's pericarps for bioethanol production, Iranica Journal of Energy \& Environment 1(4): 275-279.

[13]. Lebaka Veeranjaneya Reddy, Obulam Vijaya Sarathi Reddy2 and Young-Jung Wee. 2011. Production of ethanol from mango (Mangifera indica L.) peel by Saccharomyces cerevisiae CFTRI101, African Journal of Biotechnology Vol. 10(20), pp. 4183-4189

[14]. Kumar, J. V., Shahbazi, A. and Mathew, R., (1998), Bioconversion of solid food wastes to ethanol, Analysts, 123, pp 497-502.

[15]. Morris, W. and Sarad, R. P., (1990), Biotechnology of biomass conversion: fuels and chemicals from renewable resources, Open university press, Milton Keynes, 235.

[16]. Adams, M. R. and Flynn, G., (1982), Fermentation ethanol: an industrial profile, Tropical products institute, London, pp 1-19. 